\title{
TAX COMPETITION AND TAX CO-OPERATION IN THE EU
}

\author{
THE CASE OF SAVINGS TAXATION
}

\author{
Katharina Holzinger
}

\begin{abstract}
It took the European Union (EU) 35 years to achieve a co-operative agreement on co-ordinated measures of savings taxation. Political science has offered two explanations for this. First, co-operation is difficult to achieve as a result of heterogeneity. Countries with a small domestic tax base favor tax competition, while countries with a large tax base prefer tax co-operation. Second, co-operation is difficult as a consequence of specific characteristics of the collective action problem involved. The actors face a prisoners' dilemma. Both explanations have their limits. The first approach is not very good at predicting actual policy preferences of governments and the second approach dismisses the fact that the EU offers cooperative institutions that should be able to resolve a dilemma. The paper refines these explanations such that the theory fits better the empirical positions of EU governments and their problems of finding an agreement.

KEY WORDS • EU policy $\bullet$ financial markets $\bullet$ savings taxation $\bullet$ tax competition, tax co-operation
\end{abstract}

\section{Introduction}

The growing importance of international tax competition has two sources. As Dehejia and Genschel (1999: 403) put it: 'As the level of taxation reaches 30,40 , or even 50 percent in welfare states, the premium on tax avoidance and tax evasion rises. At the same time, the costs of doing so go down.' The level of economic integration and the liberalization of markets, especially of trade and capital markets, achieved in recent decades, have made it much easier for 
taxpayers to avoid domestic taxes by shifting their capital to a foreign country. In the case of savings taxation, the mobile tax base implies a double danger and a double temptation for national governments. A high-tax government may lose not only some of its tax revenue through capital flight, but also the economic and political benefits associated with a large domestic capital stock and capital market. With low tax rates governments can attract capital from high-tax countries and thus improve economic figures and political benefits, and sometimes also tax revenue. As a consequence of this strategic situation, tax competition may lead to a 'race to the bottom' of tax rates (Frey 1990; Sinn 1990, 1997).

In the case of the European Union (EU) there were even suspicions that this could mean that it would turn into a 'single (large) tax haven' (Giovannini and Hines 1991: 172). However, as low tax rates might also lead to a loss of revenue, European governments should be interested in co-operation in matters of savings taxation. Harmonization of tax rates or other co-ordination mechanisms in EU member states can help to prevent tax evasion and capital flight. Such a solution should be possible because the EU has the potential of enforcing a co-operative agreement.

However, until very recently, the co-ordination of savings taxation in the EU has not been very successful. Over the last 35 years, several attempts of the European Commission (EC) and EU member states to harmonize national policies on savings taxation have failed. Finally, a preliminary agreement was reached in June 2000, which was - after some changes - confirmed by the European Council in June 2003. Although this agreement is surely an achievement in preventing capital movements induced by tax differentials, it still mirrors the conflict between two groups of member states: those who want to prevent tax evasion and capital flight from their countries, and those who have a strong interest in attracting foreign capital.

Why has European co-operation in the area of savings taxes proved so difficult to obtain? In an attempt to answer this question, the paper offers an analysis based on public good theory and matrix game analysis. It builds on theoretical explanations of the European co-operation failure provided by Bucovetsky and Wilson (1991), Kanbur and Keen (1993), Genschel and Plümper (1997), and Dehejia and Genschel (1999). It develops a common framework for analysis, refines the existing theory and shows that this way the theory fits the data much better. 
The paper provides no empirical explanation in a strict meaning, because it is not concerned with many cases. It provides a rational reconstruction of a case of co-operation within the EU, which qualifies as an 'analytical narrative' as proposed by Bates, Greif, Levi, Rosenthal and Weingast (1998). The simple game theoretical framework used for analysis makes the case study comparable to others analyzed by the same technique. When we are confronted with small $N$ and many causal factors, such an approach provides a middle course between idiographic description and quantitative study. Causal factors can be reduced to the ones most important in the case under scrutiny, and can be systematically varied in comparisons with other cases, which are similar in some respects and different in others. The formal approach can help to sort out the regular effects of certain (combinations of) factors.

There lies also a potential for generalization. EU savings taxation is an example of international co-operation in the case of a transnational common good. There are numerous other transnational common good problems, such as environmental, health, or global resource problems. The chances for co-operation vary with the properties of the common goods concerned (e.g., is it a pure public good or a commons?), with the properties of the actors (e.g., are the actors homogeneous or heterogeneous, and in which respect?), and with the properties of the institutions already present (e.g., do we have an institution which has the potential to sanction defections?). Many combinations of such properties are conceivable and thus we have too many variables and not enough cases to do large- $N$ studies. Variations of this kind can, however, be represented in simple games, and the predictions derived can be confronted with empirical results in individual cases. This way, a stock of case analyses can be built up, which allows the drawing of general conclusions, for example on the effects of types of goods on cooperation.

Section 2 refers to the literature on tax competition. In Section 3 an overview of the attempts to harmonize savings taxation in the EU is presented. Section 4 provides a game-theoretic analysis of the tax co-operation problem. In Section 5 it will be shown that the models presented here can rationalize most of the actual positions of EU member states, as well as the difficulties of reaching an agreement. 


\section{Literature on Capital Income Tax Competition}

It is generally accepted that in the presence of capital mobility and in the absence of international co-ordination taxes on capital, both corporate and private savings taxes tend to be too low and that tax competition may lead to a downward spiral of tax rates and fiscal revenues (Frey 1990; Sinn 1990; Fuest and Huber 1999). Whereas most of the literature presents anecdotal rather than systematic evidence, Thomas (2002: 272) provides some OECD data that shows that the corporate income tax share of total tax revenue has decreased sharply in a number of large countries since the 1950s. A study by Devereux, Griffith and Klemm (2002) provides systematic evidence on the development of corporate income taxes since the 1960s. Their finding is that effective tax rates on corporate income have declined but that the revenue from these taxes has remained stable or even increased. For the taxation of interests on savings, Dehejia and Genschel (1999: 415f.) show that there was also a decline of tax rates employed in EU member states. Thus, tax competition exists, even though its effect on tax revenues remains unclear.

In economic theories of tax competition, two contrasting views can be found on the desirability of tax competition (Keen 1993). In the literature on public finance, tax competition is considered to have negative effects on public welfare. Tax competition leads to underprovision of common goods, and tax harmonization in the EU would therefore increase overall welfare (Bucovetsky and Wilson 1991). The public choice literature, conversely, emphasizes the fact that governments are not benevolent actors and that their interests do not coincide with those of taxpayers, which gives rise to 'political distortions' (Frey and Eichenberger 1996) and waste of tax money. Tax co-ordination is considered to be a cartel of governments at the cost of the taxpayer, while tax competition is a welfare-increasing check on governments. Constitutional rules that forbid tax co-ordination are thus, according to this view, desirable (Brennan and Buchanan 1980). Finally, there are economic models that use an objective function for governments that includes two variables: the welfare of the citizens and a 'waste' variable that accounts for imperfections in the political process and inefficiency of government spending (Edwards and Keen 1996; Eggert 2000; Fuest and Huber 1999; Fuest 2000; Myles 2000). Not surprisingly, in these models, the effects of tax co-ordination on welfare are ambiguous. 
In this paper no such normative questions are posed. I am not concerned with welfare or with the taxpayer's benefit. Here I am interested in the rational reconstruction of co-operation among governments who compete for a mobile tax base. How can it be explained that co-operation of governments in order to avoid 'harmful tax competition' emerged so slowly? Political science research has offered some elements of explanation of the European failure to co-operate. Two main arguments have been put forward: First, cooperation in the case of capital tax harmonization is difficult to achieve as a result of the heterogeneity of countries. Second, co-operation is difficult to maintain as a consequence of specific characteristics of the collective action problem involved.

Prominent representatives of the first approach relate heterogeneity to the fact that member states differ in size (Bucovetsky and Wilson 1991; Kanbur and Keen 1993; Dehejia and Genschel 1999). Countries are heterogeneous with respect to the size of their tax base. Dehejia and Genschel (1999) have argued convincingly that it pays more for small countries to prey on their neighbors' capital by applying lower taxes than it does for large countries. The reason for this is the fact that, in an open economy, tax revenue is not linear in the tax rate. Savings tax revenue increases with the tax rate for some time but, with very high tax rates, the revenue strongly decreases, because the tax base moves to another country with lower tax rates. It pays for a country to prey on the other countries' capital as long as the tax-base effect from the attracted foreign capital (increase of revenue) is greater than the tax-rate effect from domestic capital (decrease of revenue). The smaller the domestic tax base and the more capital can be attracted - that is, the larger the foreign capital base - and the higher the tax differential, the more it pays to follow a low-tax strategy. Therefore, small countries are in a much better position in tax competition than large ones. Large countries, however, can try to limit the small countries' prey by keeping the tax differential small, which may lead to a downward spiral of tax rates (Dehejia and Genschel 1999: 410). This is valid, as long as only tax revenues are considered as elements of the governments' utility functions.

The model of asymmetric tax competition shows that small states are the winners and large states the losers of unconstrained tax competition. As Dehejia and Genschel (1999: 418) admit, however, the model is less good in predicting policy preferences for tax cooperation in the EU. A number of small countries consistently 
favored tax co-operation, while a large country, the UK, strongly opposed it for a long time. Thus, asymmetry in size and the governments' interest in tax revenue do not seem to be sufficient explanatory factors. I will introduce a complementary factor in order to explain the positions of European governments better.

Genschel and Plümper (1997: 635-9) explained the difficulty of achieving co-operation in savings taxation by two specific features of this collective action problem. They too start from the assumption of heterogeneous preferences of governments. In their interpretation, one characteristic of the situation is that the minimum-sized coalition for self-sustaining co-operation is very large in the case of savings taxes. Co-operation has to include tax havens within and outside the EU to become effective. The second distinctive feature is that non-cooperators' gains from defection increase with the number of co-operators: 'being a tax haven in a world where every other state is also a tax haven is not very profitable, but being the sole tax haven in an otherwise tax haven-free world is potentially very profitable' (1997: 637). Both observations are surely correct as empirical descriptions.

However, if it is true that the gains for defectors increase with the number of co-operators, the potential co-operators gain nothing but rather experience losses from co-operation, as long as the 'minimum-sized coalition' is not reached. Each co-operator suffers from capital flight to remaining tax havens. Thus, no countries will form coalitions as this would place them in the role of the 'sucker', no matter how large the coalition is. Defection is a dominant strategy. If gains from defections increase more strongly than gains from co-operation, the game is a dilemma game over the whole number of potential co-operators. Thus, the idea of a minimum-sized coalition contributes nothing to the explanation here: There will never be voluntary co-operation, as we face a true prisoners' dilemma. Conversely, the idea of a large minimum-sized coalition is very plausible in the context of savings taxation. However, such a constellation typically does not correspond to a dilemma but to a co-ordination game, such as assurance, chicken, or battle of the sexes. The implicit presence of two different games in the paper by Genschel and Plümper (1997) is reflected in the wider literature. Problems of tax co-ordination have been modeled as a prisoners' dilemma (Hallerberg 1996), as a co-ordination game (Radaelli 1998), or as a pure conflict game (Dehejia and Genschel 1999). 
In my analysis I will characterize more precisely the relationship between the two factors emphasized by Genschel and Plümper, and I will clarify which kind of strategic constellation is the most adequate model of the savings taxation problem. Modeling the strategic constellation is a worthwhile experiment, as these models reveal not only information about the chances for voluntary cooperation and co-ordination in anarchic environments, but also about problems of finding agreement when co-operative institutions are present. It will be shown that the EU's savings tax problem does not solely arise from the problem of potential defection; it is also a problem of finding agreement, and a problem of a global collective good.

\section{History of Savings Tax Co-ordination in the EU}

The EC set up the first expert committee with the aim of analyzing the effects of different savings taxation policies of the member states upon the functioning of the common market as early as 1960 (Hahn 1988). However, the first program on the harmonization of direct taxes was not published until 1967, after a French initiative aimed at concerted measures with respect to direct taxes. Among the problems addressed in this program was savings taxation (EC 1967).

\subsection{The Commission Proposal of 1967}

The Commission identified three problems of different taxation policies among the member states (EC 1967: 10-11):

(1) Double taxation of capital income from foreign investment led to barriers to the free movement of capital. Double taxation means that in the 1960 s there were not only personal income taxes on savings income from foreign investment to be paid in the country of the owner, but sometimes additional withholding taxes on interests in the foreign country. Withholding taxes are taxes on interests, which banks automatically 'withhold' and transfer to the financial authorities. Withholding taxes may apply either to domestic or to foreign capital, or to both.

(2) Double taxation implied an incentive to invest more capital in countries with no or low withholding taxes. Thus, different withholding tax rates led to distortion of capital allocation: In terms 
of economic efficiency, capital should be invested where interests are highest, and not where taxes are lowest.

(3) As capital investment in foreign countries is difficult to monitor, tax evasion is easier with foreign than with domestic investments. Moving capital abroad in order to save taxes pays only if foreign taxes are lower than domestic ones. The lower the foreign withholding tax rate, the greater is the benefit from tax evasion. Therefore, for tax evaders, the incentive to invest more capital in low-tax or no-tax countries is even stronger. This, again, leads to distortion of capital allocation.

The EC discussed two solutions to these problems (EC 1967: 1213). The first solution combined the abolition of withholding taxes with the development of a transboundary system of information exchange. In such a system, banks in the countries of investment would inform the fiscal authorities in the countries of residence of capital owners about their earnings from interest or dividends. An information exchange system is an optimal solution, since it both avoids distortion of capital allocation and prevents tax evasion. Moreover, no harmonization of national taxes is needed. Still, the EC rejected this idea for two reasons. First, this practice would collide with the principle of bank secrecy. Second, the EC expected massive capital flight from the common market to the outside world.

The EC's preferred solution was therefore complete harmonization of withholding taxes combined with full deductibility in the country of residence. This way double taxation as well as distortion of competition for capital is avoided. However, the incentive for tax evasion remained. The higher the harmonized withholding tax rate (the smaller the difference to personal income tax), the lower is the incentive for tax evasion. On the other hand, the higher the common withholding tax rate, the greater is the incentive to invest capital outside the European market. There can be different assessments of the trade off between these two effects: some governments may prefer a high tax because their main aim is the avoidance of tax evasion; others might prefer a lower tax because of fear of capital flight outside Europe.

Accordingly, the member states reacted differently to the proposal (Genschel 2002: 138f.). Conflict centered mainly on the level of the withholding tax rate. France, Belgium, and Italy preferred a higher level than the proposed $10 \%$, as they wanted to avoid tax evasion 
and a decrease of tax revenues. The Netherlands and Luxembourg rejected the rate as too high, because they were interested in efficient capital markets, and the free movement of capital. The Council of Finance Ministers did not come to an agreement. Thus, the first attempt at harmonizing savings taxes ended in failure.

\subsection{The EC's Proposal of 1989}

The next initiative to harmonize savings taxation was launched by the EC in 1989 within the framework of the internal market program (EC 1988). At that time, double taxation was no longer a problem within the Community, as practically all member states had introduced some kind of deduction of foreign withholding taxes from domestic personal income taxes (Genschel 2002: 142). The EC focused therefore on the problem of distortion of capital allocation as a result of tax evasion.

From the beginning, the proposal was not very ambitious (EC 1989). Again, the idea of an information exchange system was rejected by the EC. At the heart of the proposal was a minimum withholding tax on interests of $15 \%$, where some exceptions were possible. As the tax rate was low, compared to income tax rates, there was still a considerable incentive for tax evasion. As a consequence, distortion of capital allocation was only slightly reduced, but not avoided.

The reaction of the member states to this proposal was again divided (Genschel 2002: 147f.). France and Italy requested a higher tax rate and the inclusion of dividends; Belgium and Portugal criticized the exception of Eurobonds; Denmark and the Netherlands preferred an information exchange system. On the other hand, the UK and Luxembourg were completely against a common solution, as they feared capital flight from the internal market. This time, the position of Germany turned out to be pivotal. Germany had introduced a national withholding tax on interests in January 1989, and then surprisingly decided to abolish it in April 1989. There were several reasons for this. First, there was an immediate response of the capital markets: Massive capital flight took place and as a consequence, interest rates increased, bonds turnover decreased, and the exchange rate for the German mark decreased (Genschel and Plümper 1997: 632). Second, as a result of a relatively flourishing economy there were no budgetary problems in Germany at that 
time. Finally, voters had reacted negatively to the tax. As a consequence of this change of German policy, the proposal for a harmonized withholding tax rate at the European level failed again.

\subsection{The EC Proposal of 1998}

During the 1990s conditions changed. In 1992 Germany reintroduced its withholding tax. This led to capital export to Luxembourg and considerably lower tax revenues than expected (Genschel and Plümper 1997: 633). Luxembourg's neighbors, especially Belgium, France, and Germany, felt disadvantaged by its refusal to introduce any kind of taxation of foreign capital income (Genschel and Plümper 1997: 632). As a result of the economic recession, most EU member states faced serious budgetary problems, which were aggravated by the fact that the governments were required to meet the rigid criteria for the European Monetary Union (EMU). Additionally, international liberalization of capital markets had made the problem of capital flight more severe. In this situation a memorandum of the EC warned that tax evasion, tax revenue losses, and distortion of competition in the European capital markets required a common policy against capital flight (EC 1996). In 1997, the EC proposed the so-called tax-package, a number of measures in the areas of corporate and interest taxation (Bernauer 2000; Thomas 2002; Radaelli 2003). The Council of Ministers charged the EC with developing another proposal for a directive on interest taxation.

The EC's proposal of 1998 relied on the harmonization of withholding taxes on transboundary capital income only, while taxes on domestic interests from capital could still be different (EC 1998). Second, the proposal was based on the so-called co-existence model: member states should be allowed to opt between a harmonized withholding tax and a European information exchange system. Obviously, there was no agreement possible between those countries favoring a system based on harmonized withholding taxes and those favoring the information exchange system. The coexistence model is a compromise, which, in practical terms, is a rather complicated solution to the problem. However, countries not revealing information about interests earned by foreigners to their home countries must at least withhold some minimum percentage of the interests. This way the incentive for tax evasion decreases. Third, the proposal included an obligation for the EU to negotiate 
guarantees with some third countries that savings of EU citizens would be taxed at the same level as they would be within the EU.

During the negotiations that followed within the Council, these provisions were further watered down. The member states' positions differed on the tax rate and the division of the withholding tax revenue between countries. Luxembourg, Austria, and the UK argued that the co-operation of all relevant third countries should be a precondition for the European solution. Negotiations again failed at the 1999 summit of Helsinki.

In June 2000, the agreement of Feira was made possible by a change of position by the British government (Genschel 2002: 143). Britain introduced a national system of information exchange for banks and fiscal authorities, and now argued at the European level that only such a system could secure sufficient protection against tax evasion. With the exception of Luxembourg and Austria, all member states now agreed on a European system of information exchange. Austria and Luxembourg declared that they would not sacrifice their bank secrecy policy, because the relevant third countries would also not do so.

\subsection{The EC Proposal of 2001}

In the event the Commission revised its proposal (EC 2001). Now, the final solution was to be based on a system of information exchange, while the co-existence model should apply only for a transitional period of about 10 years. In the meantime, negotiations of the EC with Switzerland, Liechtenstein, Monaco, Andorra, San Marino, and with the USA, were to guarantee that these countries introduce equivalent measures (European Council/Ecofin 2000). From 2011 onward all countries should be obliged to use an automatic reporting system. For the transitional period three countries were permitted to apply a minimum withholding tax of $15 \%$ during the first three years and $20 \%$ during the remaining four years on non-residents' interest income. These countries were Luxembourg, Austria, as well as Belgium, which now also opted for the withholding tax.

At the end of 2001 the EC started to negotiate with the third states. It reported to the Council on the results of these negotiations in November 2002 (EC 2002). Although the USA refused to conclude a formal contract with the EU, it caused no major problem, as it is a proponent of the automatic reporting system. There are 
already a number of bilateral agreements on information exchange with EU member states. The USA is prepared to further develop the system of information exchange, to conclude further agreements with other EU member states, and it showed interest in also developing reporting systems with Austria, Belgium, and Luxembourg.

Negotiations proved more difficult with Switzerland. It is not prepared to introduce an automatic reporting system, and it is not even willing to apply 'information exchange upon request,' as is foreseen in the OECD's (2002) model agreement on exchange of information on tax matters. Instead, Switzerland proposed applying a withholding tax on the interest income of non-residents of up to $35 \%$, if Austria, Belgium, and Luxembourg also applied such a rate. Switzerland's willingness to conclude such an agreement, however, depends on the condition that the EU negotiates 'equivalent measures' with a number of other states, namely Hong Kong, Singapore, Canada, and Japan.

The positions of Andorra, Liechtenstein, Monaco, and San Marino are similar. All seem prepared to levy a withholding tax on non-residents of about $15 \%$ to $20 \%$. They are unwilling to introduce an automatic reporting system, and - with the exception of San Marino - they are unwilling to agree to information exchange upon request. These countries can be expected to change their position if Switzerland does so.

On the basis of these results, the EU Council negotiated the proposed directive again in December 2002 and January 2003. The agreement of 21 January 2003 again includes the co-existence of the two systems. Twelve member states were to introduce an automatic system of information exchange in January 2005. Belgium, Luxembourg, and Austria were to apply a withholding tax. The rate was to be $15 \%$ from $2005,20 \%$ from 2008 , and $35 \%$ from 2011 onward. The three states were to change to an automatic reporting system only after Switzerland and the other tax havens agreed on systems of information exchange upon request (OECD rules). The revised proposal of the directive was finally adopted on 3 June 2003 (Financial Times Germany 3 June 2003).

This agreement mirrors the conflicts and divergence of governments' interests within and beyond the EU. There were still two groups of countries: those who preferred automatic information exchange, and those who were prepared to accept only minimum withholding taxes. The agreement allowed for the permanent 
co-existence of these two systems, as the general introduction of information exchange within the EU depended on Switzerland's and the other third states' willingness to accept OECD rules on information exchange upon request, as well as on negotiations with further non-EU countries, which Switzerland wanted to have included in the co-operative arrangement.

\section{Analysis of the Strategic Constellation}

This section provides an analysis of the co-operation problem based on public goods theory and matrix games. First, harmonization of savings tax policies is analyzed as a problem of providing a common good. Second, a basic model of tax co-ordination among homogeneous states is presented. Two forms of heterogeneity are then introduced into the model: heterogeneity of the utility functions of governments, and heterogeneity of states with respect to their size.

\subsection{Tax Harmonization as a Common Good}

The problem of the collection of taxes on savings by several governments in a common market where capital is perfectly mobile can be seen as a common pool resource problem (Koelliker 2001). Common pool resources are defined by two properties: rivalry in consumption and non-excludability. In the tax case, the resource is savings. The states 'exploit' the resource, and tax revenue and other gains from capital are their payoff. Consumption is rival, as savings can only be taxed up to $100 \%$ and capital can only be invested in one or in another country. Foreign governments cannot be excluded from benefiting from the capital invested by citizens of one country because capital is mobile. If there were only one user of the resource (one government would tax the complete savings) the problem would reduce to an optimization problem comparable to those in cases of renewable resources (Perman, Ma, and McGilvray 1998). If there are more users of a common resource a strategic dimension is added and a collective action problem arises.

Savings taxation is distinct from the problem of common use of the village green where all inhabitants can graze their sheep. In the tax case the users are confined to their territories while the resource 
is mobile. In this respect it is similar to fishing problems, where the fishermen are assigned to a certain territory, whereas the fish is mobile. If there is too much harvesting pressure in one territory, the resource moves to another. The 'fish,' so to speak, are attracted by low taxation and leave the country in the case of high taxation. Taxpayers can move their capital to another territory where the tax rate is lower or where there is no tax at all.

The possibility of out-migration reveals another property of the savings tax case: As long as there is only one single country with lower or no taxes, the capital can move there. Co-ordinated savings taxation is a so-called weakest-link common good. Hirshleifer (1983) distinguishes public goods according to their aggregation technology. There are three basic types of goods: standard additive 'summation' goods, where the amount of the good grows with each contribution; 'best-shot' goods, where one contribution is sufficient to provide the good; and 'weakest-link' goods, where each contribution is needed to achieve the good. In the latter case, the 'weakest link' determines which level of the good can be achieved.

Savings taxation clearly belongs to the weakest-link type: the common good is the ability to effectively collect tax from capital owners in the common capital market. Governments will only achieve this goal to the extent that they co-ordinate their taxes and tax rates. If there is a weakest link, that is, a country with no or low tax rates, capital will move into this country. This model is stylized as capital transfer is not costless, capital is not perfectly mobile for other reasons, and as tax havens need to build up capacities to attract capital. For some countries these hurdles may be low (Genschel and Plümper 1997: 636), especially in Europe and the developed world. Nevertheless, not all countries qualify as tax havens. Thus, if not all countries, at least all potential tax havens have to be included into the chain of co-operation. The weakestlink character of the problem is represented in all of the following models.

Different aggregation technologies result in different strategic constellations. In terms of matrix games, summation technology in general leads to a prisoner's dilemma, weakest-link technology to an assurance game, and best-shot technology to a chicken game (Sandler 1997: 46-59; Holzinger 2001). Thus, in the case of savings taxation, the strategic constellation can be expected to be a coordination game, or, more specifically, an assurance game. 


\subsection{Tax Competition: Co-ordination Game or Dilemma?}

In this section a model of tax co-ordination will be introduced where two governments compete for a mobile tax base. They have the choice to levy a savings withholding tax, $T$, or not to do so, $\sim T$. Countries $A$ and $B$ are identical with respect to size of capital stock and to the preferences of governments. Capital is perfectly mobile between the two countries, capital owners are perfectly rational, and there are no transaction costs. This implies that there is complete capital flight from country $A$ to country $B$, if $A$ levies the tax, while $B$ does not. The same were true if country $A$ would apply a high tax rate and country $B$ a low one.

The payoff function for the government includes two elements. The first element is the political benefit from savings tax revenue, $r$, which is determined by the tax rate, the tax base, and a function that turns tax revenue into political benefits for governments. Governments can spend tax revenue in a way that helps them to win the next elections. Conversely, a high budget deficit can imply a loss of votes.

The second element is the political benefit, $f$, associated with the domestic financial market. A flourishing banking and finance sector, sufficient capital supply, low interest rates, investment, innovation, growth, and high employment are (partly) a consequence of a large and sound capital market. A flourishing finance sector may also raise tax revenue from this sector. Thus, savings tax losses caused by a low tax rate can be partly compensated by higher corporate taxes from the banking sector - the exact extent depending on the relative size of savings capital and the financial sector's value added. Since the state of the economy plays a great part in voters' evaluations of a government's performance, these benefits are not only economic but also political ones.

It is difficult to measure the political benefits from tax revenue and from the financial sector. It can be assumed, however, that there is a positive correlation of a well-functioning capital market, its positive economic effects, and political benefits from it. Similarly, a positive correlation between the level of tax revenue and political benefits can be assumed: the higher the revenue the more can be spent, and the less critical is the public of the governments' performance.

There is a subjective factor in the values of the political benefits both from tax revenue and from a flourishing financial market. The payoffs depend on the governments' relative valuations of $r$ 
and $f$. To be precise we should talk about the values of $r$ and $f$ for the government and denote $u(r)$ and $u(f)$. Governments will not in any case value the political benefits from tax revenue more than those from the financial market, or vice versa. Their valuation will depend on the actual circumstances. For example, if the overall budgetary situation is positive, a government may be much more interested in the political benefits of a large capital market, whereas in a situation of high budget deficit, the revenue may become more important. A government that is susceptible to the interests of the financial sector might prefer to keep the domestic capital stock as large as possible and sacrifice tax revenue. This could be a consequence of the hard lobbying by the financial sector or of the fact that it is a relatively large sector within this country's economy. Thus, sometimes a government may be revenue-oriented $(u(r)>u(f))$, and sometimes financial market-oriented $(u(f)>u(r))$. To keep the notation simple, this can be approximated by assuming $r>f$ or $f>r$. If we could measure $r$ and $f$, and if the governments' utilities were a linear transformation of $r$ and $f$, it would in any case be equivalent.

The first model assumes revenue-oriented governments. Table 1 gives the payoffs for the two identical countries $A$ and $B$ for each strategy combination. The benefit from tax revenue can only be realized when both governments levy the tax. If a government itself levies no tax, there is no tax revenue; if the other government applies no tax the capital moves out. There are political benefits, $f$, from domestic capital, when both governments have a tax, or when both do not. A government that levies no tax gains the political benefit of both domestic and foreign capital $(2 f)$, as foreign capital migrates in. A government that introduces a tax has no political benefits from the financial sector at all, because the domestic capital moves out. The first preference of the governments is thus that both have a tax, the second that only the other government has a tax, the third that both have no tax, and the least preferred situation is that they themselves levy the tax, while the other government does not.

The game in Table 1 belongs to the class of co-ordination games. More precisely, it is an assurance game, which has both a Paretooptimal and a sub-optimal Nash equilibrium. This confirms the expectation for weakest-link goods. Only if there is no weakest link, will the common good (savings tax revenue for both states) be provided. If there is a weakest link, one single tax haven in this 
Table 1. Savings Tax Co-ordination with Revenue-oriented Countries Assumption $r>f \geq 0$

\begin{tabular}{lllllll}
\hline & $\begin{array}{l}\text { Strategy } \\
\text { combination }\end{array}$ & $\begin{array}{l}\text { Tax } \\
\text { revenue }\end{array}$ & $\begin{array}{l}\text { Political } \\
\text { benefits }\end{array}$ & Payoff & Ordinal \\
\hline Country $A$ & A: $T$ & B: $T$ & $r$ & $f$ & $r+f$ & 4 \\
& A: $T$ & B: $\sim T$ & 0 & 0 & 0 & 1 \\
& A: $\sim T$ & B: $T$ & 0 & $2 f$ & $2 f$ & 3 \\
& A: $\sim T$ & B: $\sim T$ & 0 & $f$ & $f$ & 2 \\
\hline
\end{tabular}

Note: All factors are identical for country $B$.

Game Matrix

Country $B$

\begin{tabular}{|c|c|c|}
\hline & $\operatorname{Tax}$ & No $\operatorname{tax}$ \\
\hline $\operatorname{Tax}$ & $\begin{array}{c}r+f, r+f \\
4,4\end{array}$ & $\begin{array}{r}0,2 f \\
1,3\end{array}$ \\
\hline No Tax & $\begin{array}{l}2 f, 0 \\
3,1\end{array}$ & $\begin{array}{r}f, f \\
2,2\end{array}$ \\
\hline
\end{tabular}

case, the good will not be achieved. There is no tax revenue, although one government enjoys double political benefits from the financial sector. In the case of two tax havens, the good will not be provided, but there are equally distributed political benefits: There is no capital flight, but no tax revenue, either.

It should be easy to find a solution to this collective action problem. Communication of the two governments should be sufficient. They should agree on the strategies to levy the withholding tax, as this is the optimal equilibrium. Thus, tax co-ordination should be easy to achieve. This does not at all correspond to the above observations of attempts to harmonize tax policies in the EU. The assumptions of the model are not yet sufficiently realistic.

In the following model, financial market-oriented governments are assumed. This is captured by the assumption that financial market benefits are greater than savings tax revenue benefits $(f>r)$. The payoffs in Table 2 are constructed as in Table 1; however, their value, and thus the preference order, changes. The game is 
Table 2. Savings Tax Competition with Benefits-oriented Countries Assumption $r>f \geq 0$

\begin{tabular}{lllllll}
\hline & $\begin{array}{l}\text { Strategy } \\
\text { combination }\end{array}$ & $\begin{array}{l}\text { Tax } \\
\text { revenue }\end{array}$ & $\begin{array}{l}\text { Political } \\
\text { benefits }\end{array}$ & Payoff & Ordinal \\
\hline Country $A$ & A: $T$ & B: $T$ & $r$ & $f$ & $r+f$ & 3 \\
& A: $T$ & B: $\sim T$ & 0 & 0 & 0 & 1 \\
& A: $\sim T$ & B: $T$ & 0 & $2 f$ & $2 f$ & 4 \\
& A: $\sim T$ & B: $\sim T$ & 0 & $f$ & $f$ & 2 \\
\hline
\end{tabular}

Note: All factors are identical for country $B$.

Game Matrix Country $B$

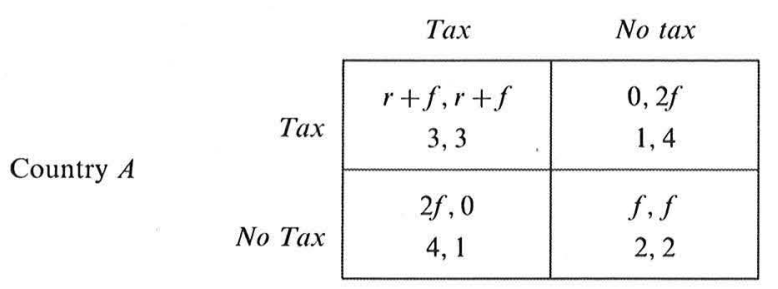

now a prisoners' dilemma. The Nash equilibrium implies tax competition and no tax at all, or a 'race to the bottom' of tax rates. Even if the players agree on a contract to play Pareto-optimal outcome strategies $(T, T)$, they both have an incentive to defect afterwards.

The sub-optimality of this strategic constellation should be obvious to the EU member states. For a relatively small number of states, which are in a permanent relationship in their capacity as EU members, it should thus not be too difficult to find a negotiated agreement. The EU institutions have both the authority to decide on a co-operative outcome and the power to secure compliance. Furthermore, reactions and retaliation by other member states must be expected. Thus member states should agree on the co-ordinated solution, since this would guarantee all states a higher payoff than the tax competition equilibrium. Why was there not even a negotiated agreement for such a long time? One possible explanation is that not all member states consider tax co-ordination to be individually better than tax competition. The background for this is the heterogeneity of preferences among EU member states. 


\subsection{Tax Competition of Heterogeneous Member States}

Not all European states are in the same situation with respect to financial markets and tax revenue. Governments may have heterogeneous preferences for many reasons. Their financial sectors and capital markets are different in size and development; their economies may do well or may suffer from a recession; budget deficits may be more or less severe; capital income may account for more or less of overall personal income, and thus the savings tax would have a correspondingly larger or smaller share of the states revenue; taxpayers may be more or less prone to tax evasion. This variance in circumstantial factors will lead to different relative valuations of tax revenue and political benefits.

The next step is to introduce heterogeneity. It is sufficient to distinguish two types of governments: those which are revenueoriented $(r>f)$ and those which are financial market-oriented $(f>r)$. Revenue-oriented governments value tax revenue from savings taxation higher than financial market benefits, for example because they are confronted with severe budget deficits, or because the financial sector is less important in terms of size in this country and thus cannot contribute much to economic benefits of corporate tax revenue. Financial market-oriented governments value political benefits from the financial sector higher, for example, because in terms of the national product the share of financial sector and/or its share in corporate tax revenue is large - because the sector is very active in lobbying, or because there are no budgetary problems - and the savings tax is thus not considered so important.

The payoffs are as in Tables 2 and 3. Let government $A$ be revenue-oriented and government $B$ be financial market-oriented. The game matrix in Table 3 represents an asymmetric dilemma or unilateral defection game. There is a unique and sub-optimal Nash equilibrium as in the prisoners' dilemma. The game is different from the prisoners' dilemma, however, because only the financial market-oriented government, $B$, has a dominant strategy not to tax; the revenue-oriented government prefers to levy the $\operatorname{tax}$, if $B$ does as well; but it prefers not to tax, if $B$ does not.

This game combines a defection problem with a distributional problem. If the governments agree to tax co-ordination $(T, T)$, only government $B$ has an incentive to defect afterwards. However, there is a distributional problem, as the Pareto-optimal tax coordination outcome represents the first preference for government $A$, 
Table 3. Savings Tax Competition with Heterogeneous Countries Assumptions Country $A$ : $r>f$

Country $B: f>r$

Game Matrix

Country $B$

\begin{tabular}{|c|c|c|c|}
\hline & & $\operatorname{Tax}$ & No $\operatorname{tax}$ \\
\hline \multirow{2}{*}{ Country $A$} & $\operatorname{Tax}$ & $\begin{array}{c}r+f, r+f \\
4,3\end{array}$ & $\begin{array}{r}0,2 f \\
1,4\end{array}$ \\
\hline & No Tax & $\begin{array}{c}2 f, 0 \\
3,1\end{array}$ & $\begin{array}{l}f, f \\
2,2\end{array}$ \\
\hline
\end{tabular}

but only the second preference for government $B$. The latter would prefer the second Pareto-optimal outcome $(T, \sim T)$.

This model is based on the subjective preferences of governments, i.e., on their heterogeneous valuations of $r$ and $f$, which implies a methodological problem if the model is to be tested empirically. On the one hand, it is governments' preferences that count in an explanation of strategic interaction of governments in the EU. On the other hand, the subjectivity of preferences makes their use as explanatory factors problematic. Preferences cannot be observed directly.

There are basically two strategies of dealing with this problem. First, the actors can be asked what their preferences are and some utility measurement or indicator can be developed. As this is difficult to get from governments, a similar strategy would be to use the reasons governments give publicly as justifications for their positions. There is no guarantee, however, that the reasons given are the 'true' reasons. Second, preferences can be inferred after behavior has been observed. For example, if a government has objected to the introduction of a common withholding tax, it can be concluded that it preferred no tax to be introduced. However, this does not tell us why the government had these preferences. Therefore, it is of no use for predictions.

It would thus be more desirable to have a model that relies on the objective elements in the governments' payoff functions. There are 
indicators that can be measured: the size of a country's tax base and the size of the financial sector, for instance. These indicators can be used as explanatory variables if the theoretical assumption is valid that governments' utility functions consist of monotone functions of $r$ and $f$, where $f$ is a measurable indicator. The outcome of the strategic interaction can then be explained as a result of heterogeneous conditions.

Next, a model is developed that relies on a single objective factor, namely, the size of a country. Both countries have the same preference for tax revenue, but the size of their tax base is different. This model is based on the argument presented in the literature that by the way of tax competition small countries experience welfare gains (Bucovetsky and Wilson 1991) or tax revenue gains (Kanbur and Keen 1993; Dehejia and Genschel 1999) at the cost of large countries.

The size argument will be translated into the matrix game language used here. Country $A$ is large, $c_{A}$, while country $B$ is small, $c_{B}$, thus $c_{A}>c_{B}$. Both governments have two strategies: They can apply a high tax rate, $t_{H}$, or a low tax rate, $t_{L}$, with $0<t_{L}<t_{H}<1$. Capital is again perfectly mobile and there are no transaction costs. This implies complete capital flight from the hightax country to the low-tax country, if there is no tax co-ordination. I further assume that for the small country, $B$, the positive foreign tax-base effect, $c_{A} t_{L}$, of low taxes is greater than the negative domestic tax-rate effect, $c_{B} t_{H}-c_{B} t_{L}$; and that for the large country, $A$, the negative domestic tax-rate effect, $c_{A} t_{H}-c_{A} t_{L}$, of low taxes is greater than the positive foreign tax-base effect, $c_{B} t_{L}$. Therefore, in the case of tax competition, government $B$ prefers low taxes, while government $A$ prefers high taxes. Given these conditions, government $B$ may benefit from undercutting $A$ 's tax rate. Table 4 gives the payoffs for each strategy combination, as well as the preference order for both countries.

The game has the same strategic structure as the one in Table 3. It is an asymmetric dilemma, combining the defection and the distributional problem. For government $B$ the low tax rate is a dominant strategy. Its first preference is the outcome where country $A$ chooses the high tax while $B$ applies the low tax. If there were a negotiated agreement on the outcome, where both countries levy the high tax, government $B$ could be expected to defect afterwards. Thus the low tax rate is the equilibrium. 
Table 4. Savings Tax Competition of Small and Large Member States

\begin{tabular}{|c|c|c|c|c|c|c|}
\hline \multirow{4}{*}{$\begin{array}{l}\text { Countries } \\
A \text { and } B\end{array}$} & \multicolumn{2}{|c|}{$\begin{array}{l}\text { Strategy } \\
\text { combination }\end{array}$} & \multirow{2}{*}{$\begin{array}{l}\begin{array}{l}\text { Payoff } \\
\text { Country } A\end{array} \\
c_{A} t_{H}\end{array}$} & \multirow{2}{*}{$\begin{array}{l}\begin{array}{l}\text { Payoff } \\
\text { Country B }\end{array} \\
c_{B} t_{H}\end{array}$} & \multirow{2}{*}{$\begin{array}{l}\begin{array}{l}\text { Ordinal } \\
\text { Country } A\end{array} \\
4\end{array}$} & \multirow{2}{*}{$\begin{array}{l}\begin{array}{l}\text { Ordinal } \\
\text { Country B }\end{array} \\
3\end{array}$} \\
\hline & $\mathrm{A}: t_{H}$ & B: $t_{H}$ & & & & \\
\hline & A: $t_{H}$ & B: $t_{L}$ & 0 & $\left(c_{B}+c_{A}\right) t_{L}$ & 1 & 4 \\
\hline & A: $t_{L}$ & B: $t_{H}$ & $\left(c_{A}+c_{B}\right) t_{L}$ & 0 & 3 & 1 \\
\hline & $\mathrm{A}: t_{L}$ & B: $t_{L}$ & $c_{A} t_{L}$ & $c_{B} t_{L}$ & 2 & 2 \\
\hline
\end{tabular}

Game Matrix

$$
\text { Country } B
$$

\begin{tabular}{|c|c|c|c|}
\hline \multirow{3}{*}{ Country $A$} & \multirow[b]{2}{*}{ High tax } & High tax & Low tax \\
\hline & & $\begin{array}{c}c_{A} t_{H}, c_{B} t_{H} \\
4,3\end{array}$ & $\begin{array}{c}0,\left(c_{B}+c_{A}\right) t_{L} \\
1,4\end{array}$ \\
\hline & Low tax & $\begin{array}{c}\left(c_{A}+c_{B}\right) t_{L}, 0 \\
3,1\end{array}$ & $\begin{array}{c}c_{A} t_{L}, c_{B} t_{L} \\
2,2\end{array}$ \\
\hline
\end{tabular}

In fact, government $B$ may not lose much, if the tax competition equilibrium is played instead of the tax co-ordination Paretooptimal outcome. The smaller the tax differential, the closer government $B$ will be to indifference between the co-ordinated, $t_{H}, t_{H}$, and the competition, $t_{L}, t_{L}$, outcome. Therefore, it will not be easy to convince government $B$ that co-ordination of taxes is to the benefit of both governments. Although the combined tax revenues would be much higher under tax co-ordination, the gain is distributed unevenly. If this result is valid for the tax revenue component of the governments' utility function alone, it will be reinforced if political benefits from the financial sector are taken into account.

The models are stylized insofar as they make some rigid assumptions. The effects of tax competition will shrink if the assumptions of perfect capital mobility and perfect rationality of capital owners are given up. It is reasonable to assume that capital owners consider transaction costs, and the risks of transboundary capital investment are considered higher than those of domestic investment. Moreover, a certain percentage of the taxpayers may be honest and may not seek to evade taxes. This does not change the general results of the models but it does diminish the effects. 


\subsection{Results of the Analysis}

What have we gained by this analysis? There are four elements that are distinct from earlier approaches. First, the character of savings taxation co-operation as a weakest-link common good tells us that there is no 'large minimum-sized coalition', such that voluntary co-operation can be expected after the minimum-sized coalition has been achieved. Theoretically, in an anarchic world of $n$ countries, no coalition of $m$ countries, given $m<n$, can provide the good. There will be no voluntary co-operation of sub-coalitions, as long as not all potential tax havens join the coalition. If the game among governments were only about tax revenue it would be a mere co-ordination problem.

Second, the strategic constellation is, however, of the dilemma type. This is because it is not only tax revenue that is important for governments, but also, and for some governments even more so, the political benefits from a large capital market and a flourishing financial sector. The dilemma and the weakest-link character imply that co-operative institutions or binding treaties among all potential tax havens are necessary to resolve the problem.

Third, heterogeneity is an important feature of the game. However, not only does the different size account for the heterogeneity, but also the different values governments place on the two objectives in their utility function: political benefits from tax revenue and from financial markets. Governments of large countries and/or those which value tax revenue more highly than financial sector benefits prefer tax co-operation; governments of small countries and/or those which value financial sector benefits more highly prefer tax competition.

Fourth, the strategic constellation is an asymmetric dilemma. This does not only tell us that we need co-operative institutions and binding contracts, but also that we face a negotiation problem in trying to find a co-operative agreement. In an anarchic environment, there is not much difference between symmetric and asymmetric dilemmas. Players end up at the sub-optimal equilibrium in both cases. However, finding a solution in a co-operative environment is different in the two games.

In the symmetric prisoners' dilemma, both players would prefer a common tax to the Nash equilibrium of no tax. In the asymmetric dilemma it is more difficult to find an agreement in the first place. Some governments have a strong incentive to negotiate a fully 
co-ordinated solution based on a harmonized system, for example, that all apply a withholding tax, all use the same tax rate, or all use an information exchange system. Other governments have an incentive to resist full co-ordination. Even if they prefer full coordination over tax competition, their most preferred solution is non-coordination.

Thus, a negotiated solution to an asymmetric dilemma can take three forms: The first is full co-ordination of strategies $(T, T)$. This requires compensation for those countries that prefer tax competition. The second solution is non-coordination of strategies $(T, \sim T)$. This requires compensation for those countries that prefer co-operation. The third solution might be a compromise, which is neither full co-ordination, nor clearly non-coordination.

\section{Governments' Positions and Negotiation Problems}

Which elements of the attempts to co-ordinate savings taxes in the EU can these models help to understand? There are two levels of explanation. First, how can the policy positions of EU member states in the various rounds of negotiation be rationalized? Second, how can the failures to co-operate over a long period and the final outcome be explained?

\subsection{The Positions of National Governments}

In the models, the utility function of governments consists of two factors: political benefits from tax revenue and from the financial sector. To which extent can these factors explain the policy preferences of governments, namely their support for tax co-operation at EU level, respectively their preference for tax competition? The models tell us that governments will support co-operation if they are large compared to other countries, or if they do not believe their financial sector to be very important for the economy and their voter turnout. The model leaves open whether both conditions have to be met or whether one of the two conditions is sufficient, as well as which of the two factors is more important.

The tax revenue factor can be approximated by indicators for the size of a country. The financial market factor can be approximated by indicators for the importance of the financial sector within an economy. Thus, small countries with an important financial sector 
will resist tax co-operation, while large countries with a less important financial sector will favor tax co-operation. Some indicators for the EU member states, the USA, and Switzerland are given in Table 5.

The usual indicator for size is population size (e.g., Bucovetsky and Wilson 1991). This leaves us with the common assessment that there are five large member states in the EU: France, Germany, Italy, Spain, and the UK. All the others are relatively small countries and should thus prefer tax competition.

Table 5 gives three indicators for the relative importance of the financial sector within an economy: the number of employees in the banking industry as a percentage of total employees, the balance sheet total, and the value added in the banking industry, both as a

Table 5. Population Size and Importance of the Financial Sector

\begin{tabular}{|c|c|c|c|c|}
\hline \multirow[t]{2}{*}{ Member state } & \multirow{2}{*}{$\begin{array}{c}\text { Population size } \\
1999 \\
\text { (millions) }\end{array}$} & \multicolumn{3}{|c|}{ Importance of banking sector } \\
\hline & & $\begin{array}{c}\text { Employees in } \\
\text { banking } \\
\text { industry } \\
\text { (\% of all } \\
\text { employees) }\end{array}$ & $\begin{array}{c}\text { Balance sheet } \\
\text { total in } \\
\text { banking } \\
\text { industry } \\
(\% \text { of } G D P)\end{array}$ & $\begin{array}{c}\text { Value added } \\
\text { in banking } \\
\text { industry } \\
(\% \text { of } G D P)\end{array}$ \\
\hline Austria & 8.083 & 2.0 & 262 & 3.8 \\
\hline Belgium & 10.213 & 1.9 & 313 & 4.6 \\
\hline Denmark & 5.313 & 1.8 & 233 & 3.2 \\
\hline Finland & 5.159 & 1.1 & 106 & - \\
\hline France & 58.977 & 1.7 & 213 & 3.1 \\
\hline Germany & 82.037 & 2.1 & 328 & 4.1 \\
\hline Greece & 10.521 & 1.4 & 114 & 4.9 \\
\hline Ireland & 3.735 & - & - & - \\
\hline Italy & 57.617 & 1.7 & 155 & 3.4 \\
\hline Luxembourg & 0.429 & 12.0 & 3299 & 29.3 \\
\hline The Netherlands & 15.760 & 1.7 & 242 & 3.7 \\
\hline Portugal & 9.979 & 1.3 & 283 & 4.4 \\
\hline Spain & 39.394 & 1.8 & 179 & 3.8 \\
\hline Sweden & 8.854 & 1.2 & 174 & 3.1 \\
\hline UK & 59.391 & 1.8 & 313 & 4.3 \\
\hline USA & 271.626 & 1.2 & 61 & 2.3 \\
\hline Switzerland & 7.124 & 3.2 & 593 & 12.2 \\
\hline
\end{tabular}

Note: - No banking data available for Ireland.

Source: Eurostat (2001); CESifo-DICE. 
Table 6. Positions of Member States in Four Phases of Negotiation

\begin{tabular}{|c|c|c|c|c|c|c|}
\hline \multirow[t]{2}{*}{ Member states } & \multicolumn{2}{|c|}{ Factor } & \multirow{2}{*}{$\begin{array}{c}1967 \\
\text { pro or contra } \\
\text { harmonized with- } \\
\text { holding tax } \\
(+,-)\end{array}$} & \multirow{2}{*}{$\begin{array}{c}1989 \\
\text { pro or contra } \\
\text { harmonized with- } \\
\text { holding tax } \\
(+,-)\end{array}$} & \multirow{2}{*}{$\begin{array}{c}1999 \\
\text { pro or contra } \\
\text { information } \\
\text { exchange } \\
(+,-)\end{array}$} & \multirow{2}{*}{$\begin{array}{c}2003 \\
\text { pro or contra } \\
\text { information } \\
\text { exchange } \\
(+,-)\end{array}$} \\
\hline & $\begin{array}{l}\text { large or small } \\
\qquad(l, s)\end{array}$ & $\begin{array}{c}\text { important financial } \\
\text { sector } \\
(\text { yes, no })\end{array}$ & & & & \\
\hline France & 1 & no & + & + & + & + \\
\hline Italy & 1 & no & + & + & + & + \\
\hline Germany & 1 & yes & + & - & + & + \\
\hline Belgium & $\mathrm{s}$ & yes & + & + & + & - \\
\hline The Netherlands & $\mathrm{s}$ & no & - & + & + & + \\
\hline Luxembourg & s & yes & - & - & - & - \\
\hline UK & 1 & yes & & - & - & + \\
\hline Ireland & s & no & & + & + & + \\
\hline Denmark & $\mathrm{s}$ & no & & + & + & + \\
\hline Spain & 1 & no & & + & + & + \\
\hline Portugal & s & no & & + & + & + \\
\hline Greece & s & no & & + & + & + \\
\hline Austria & $\mathrm{s}$ & yes & & & - & - \\
\hline Finland & s & no & & & + & + \\
\hline Sweden & $\mathrm{s}$ & no & & & + & + \\
\hline
\end{tabular}


percentage of the gross domestic product (GDP). Among the EU member states, only Luxembourg has an outstanding value for each of the indicators. Next follows non-EU Switzerland, while the USA has the lowest values with all indicators.

Within the EU some other governments can be thought of as having an important banking industry: Belgium, Germany, the UK, and Austria. Although, compared to Luxembourg, the objective size of their banking industry in relation to other sectors is still small it is nevertheless above the EU average. Thus, these five countries are candidates for being states that might be interested in tax competition as a result of the financial market factor. Portugal and Greece have also relatively high figures for the added value, but they have much lower figures for employment. Still, they could also be candidates for a preference for tax competition. It is not clear, however, when governments perceive the financial sector as important. What counts more for them: a high percentage of employees in the sector or a high added value of the sector?

How well do predictions made on the basis of these indicators fit the factual policy preferences of the EU member states? Which explanation of positions, by size (S) or by financial sector (FS), fits the data better? In order to count the policy positions of member states I distinguish four phases of attempts to co-operate: the end of negotiations over the Commission proposals in 1967, in 1989, in 1999, and the final agreement, in 2003. The positions the member states had in the negotiations on tax co-operation are given in Table 6.

Now it can be counted for each phase which member states' positions are correctly predicted ('fit') and which are not correctly predicted ('misfit') for each of the two factors separately. The number of 'positions' is different for each phase, as the number of member states changed. The results are given in Table 7. The table shows that overall the financial sector objective fits the data better than the tax revenue objective (size), although this is not true for all phases: in the 1967 negotiation phase the tax revenue factor clearly works better.

It is plausible that both elements of the utility function, political benefits from tax revenue and from the financial sector, factually play a role in preference formation. How do these factors interact? The combination of the two factors may be such that both push the policy preferences in the same direction, either tax competition or co-operation. However, they may also constrain each other in 
Table 7. Explanation of the Countries' Positions by Size and by Importance of Financial Sector

\begin{tabular}{lcrrrrrrrrr}
\hline Phase & \multicolumn{2}{c}{1967} & \multicolumn{2}{c}{1989} & \multicolumn{2}{c}{1999} & & 2003 & \multicolumn{2}{c}{ Total } \\
\hline Factor & S & FS & S & FS & S & FS & S & FS & S & FS \\
Fit & 5 & 3 & 4 & 11 & 6 & 13 & 8 & 13 & 23 & 40 \\
Misfit & 1 & 3 & 8 & 1 & 9 & 2 & 7 & 2 & 25 & 8 \\
Total & 6 & 6 & 12 & 12 & 15 & 15 & 15 & 15 & 48 & 48 \\
\hline
\end{tabular}

the utility function. The best explanation is obviously the one that links both size and financial sector: If the hypothesis is that a state will oppose co-operation only if it is small and has a significant financial sector, then only the behavior of Belgium in the phases before the final agreement remains unexplained.

There is one alternative explanation that shall be briefly discussed here: the ideology of parties in government. The basic conjecture would be that conservative governments favor low taxes and tax competition, while socialist or social democratic governments prefer high taxes and tax co-operation. This factor is somewhat correlated to the tax revenue factor, as one can assume that left-wing governments with a preference for spending in general value tax revenue higher than political benefits from the financial sector. However, when conservative governments are confronted with large budget deficits they might as well value tax revenue higher than the financial sector benefits. In the following I give some anecdotal evidence on governments' ideology and their attitude towards tax co-operation or tax competition for the four largest EU countries.

Italy and France are large countries without important financial sectors and they consistently supported tax co-operation throughout the whole period. France never changed this position although parties in government changed several times. In Italy, there were socialist governments most of the time. However, conservative governments supported tax co-operation as well, which holds, for example, for the Berlusconi government in the final phase.

In cases where the two factors point in different directions, the policy preferences are more difficult to explain. Germany and the UK have both large tax bases and important financial sectors. It is therefore not surprising that these countries have changed positions over time. However, why did Germany for most of the time co- 
operate, while the UK for most of the time competed? Can this be explained by ideology?

In the German case, obviously ideology played not much of a role. It seemed rather the budgetary situation that was important. Conservative governments introduced, abolished and re-introduced a national withholding tax within three years. Except for a short period they were always in favor of a co-operative solution. However, the German conservative government was responsible for the failure of the $1989 \mathrm{EC}$ proposal, when it took a stance against the common tax. As already pointed out, at that time, Germany had no budgetary problems and had abolished the newly introduced withholding tax quickly after the experience of capital flight to Luxembourg and negative voter reactions. Later on, the German conservative government reversed its course, re-introduced the tax and again supported a European solution. This is consistent with the tax revenue factor, as the budgetary situation worsened after German unification; it is not consistent with ideology, however. Similarly, after 1998, the social democratic governments supported tax co-operation and increased the national withholding tax. This might be a result of ideology or again a result of the fact that they had to struggle with huge budget deficits after 2000 .

Why was the UK against tax co-ordination for such a long time? Several factors could explain this position. First, the UK was not so much threatened by capital flight to neighboring European countries as France or Germany were. The tax differential and hence the gain from tax evasion is smaller for British citizens, because the UK has the lowest personal income taxes in Europe. Second, the 'City', London's financial market, is something of a national symbol and thus politically important. Third, ideology may have played a role. During the negotiations over the 1989 initiative, the UK had a conservative government, which generally favored liberalized markets, including regulatory and tax competition, and low tax rates. It thus may have voted against a European tax cartel for ideological reasons. However, during the 1998-1999 negotiations, the UK still opposed a common withholding tax, even though Labour was now in power. The UK government argued that the demise of the City would be imminent if a common tax were introduced. UK opposition prompted the failure of negotiations in December 1998. In spring 1999, the UK surprisingly changed its position and proposed an information exchange system. It is unclear whether ideology played a role in this or whether the shift in position 
followed the introduction of a national information exchange system (Genschel 2000: 131). In sum, the UK financial sector factor seems to explain attitudes towards tax co-operation at least as well as ideology.

\subsection{Co-operation and the Negotiated Agreement}

What contribution can the models make to explaining the various failures and the final outcome of the process of savings tax cooperation in the EU? Two elements are relevant: the weakest-link character of the collective good and the strategic constellation of an asymmetric dilemma.

The weakest-link characteristic can explain several elements in the whole process. First, the fact that the EC in its proposal of 1967 chose a modest approach, that is, a low-level harmonized withholding tax instead of an automatic reporting system, was justified by reference to the outside world. There was fear of capital flight to outside the EU. Second, the 'outside world conditionality' of the compromise of Feira shows that the EU member states wished to include all relevant potential tax havens into the co-operation. Third, Switzerland only agreed to some co-operation with the EU on the basis of a further outside world conditionality. The weakest-link character was surely one element that contributed to the failure of previous attempts at tax co-ordination.

However, a co-operative solution within the EU has now been found, which includes some other states, although not all potential tax havens co-operate, as yet. How was this possible? In 1998, the OECD started an initiative to combat harmful tax competition (OECD 1998; Thomas 2002). In 2001 the OECD shifted its emphasis from targeting low tax regimes to the questions of transparency, bank secrecy, and exchange of information. After the events of 11 September 2001 this focus found worldwide support (CEPS 2001: 15). In April 2000, a report was published on improving access to bank information for tax purposes (OECD 2000). After negotiations with 20 members and 11 non-members - which are typical tax havens - the OECD (2002) published a model agreement on exchange of information in tax matters. The model agreement is about exchange of information upon request and does not include automatic exchange of information. Still, there are now prospects that there will be worldwide co-operation in matters of savings taxation on the basis of exchange of information. This international 
background has surely helped the EU member states to finally come to an agreement.

The OECD initiative can also explain the general shift from the idea of harmonizing withholding taxes to an automatic information exchange. Denmark and the Netherlands had introduced such systems domestically and had long pushed for a European automatic reporting system. It is obvious that the states which suffered most from capital flight - Germany, France, and Belgium - did not try to introduce national automatic reporting systems, because this aggravated their problem. Why did they not push for such a system at the EU level, however? From the 1960s onward, it was well known that information exchange is an optimal solution, as it does not require savings tax harmonization and it completely prevents tax evasion. Two arguments were raised against it, bank secrecy and the 'outside world constraint,' which with the OECD's initiative became obsolete.

The asymmetric dilemma explains why some governments have a strong incentive to find a co-operative solution, and thus why after some failures there were again and again attempts to find a solution at the EU - and later at the OECD - level. The EU offers a cooperative institutional structure within which dilemmas can in principle be overcome. However, other governments have an incentive to remain in the state of tax competition. The asymmetry became an obstacle to successful negotiation because tax matters require unanimity at the EU level. Thus, the latter governments could veto co-operation attempts.

How was an agreement finally possible? Without the majority rule, a solution of this negotiation problem was only possible by resorting to compensation or by compromise. There is some evidence that there has been compensation in the form of package deals for countries which favor tax competition. In the final round of negotiations Austria insisted on a solution to the problem of heavy vehicle transit across Austria before it was ready to compromise in the tax conflict (Neue Zürcher Zeitung 4 December 2002; Süddeutsche Zeitung 4 December 2002). Three of the third states the EC negotiated with got something 'in exchange.' Switzerland has requested that it be permitted to take advantage of other measures of the EU tax package; Andorra wants to officially introduce the Euro as its currency; Monaco has asked for equal rights on EU markets for financial services (EC 2002). This explains these countries' agreement to the whole package. 
Another factor is the 'split outcome,' which can be seen as a compromise solution: While those EU member states which have always favored co-operation (and the USA) will apply an information exchange system, the other EU members (and the European third states) will levy withholding taxes. This solution is not full co-ordination of strategies, but it is by no means non-coordination. For the states willing to co-operate, the application of withholding taxes is an equivalent measure if the withholding tax rates are high enough to prevent tax evasion. For the states favoring competition, this was acceptable as they may still gain from the differentiated system. As long as the withholding tax rates are below the taxes on savings and bonds in the other countries, tax-induced attraction of capital is still possible. These gains will decrease, however, as the withholding tax rate for non-residents will increase up to $35 \%$. Thus, after 2010 the tax differential might even be negative against some countries.

Since the tax rates differ widely (Krause 2001), and since future changes of rates for residents are possible in all countries, it is, however, very difficult to predict which group of countries will be the winners and which will be the losers of the split outcome. A great advantage of the information exchange system is that it prevents tax evasion but does not constrain national governments in their choice of tax rates for residents. It might well be that the states applying the automatic reporting system keep their tax rates low or even decrease them. This might eventually cause the opposing states also to join the information exchange system.

Therefore, the asymmetric dilemma with its distributional element accounts for failures of negotiations, for new attempts to negotiate, as well as for a compromise and compensation outcome, as is typical in negotiation problems. It was not the constellation of a dilemma as such that was responsible for the difficulties in resolving this issue at EU level. Rather it was the problem of finding an agreement.

\section{Conclusion}

In this paper two new elements have been introduced into the analysis of the European attempts to achieve co-operation in the field of savings taxes. First, the common good associated with this problem has been identified as a weakest-link good, that is, cooperation of all potential tax havens is needed. Second, it has been 
assumed that in capital taxation governments are not solely motivated by the benefits of tax revenue but also by the economic and political benefits from a large financial sector. Although this assumption is not uncommon, it has not been explicitly taken into account in previous models of the tax co-operation problem.

The weakest-link character explains why the EU's attempts to achieve co-operation have failed several times and why they were accompanied by 'outside world conditionalities.' An agreement at the EU level was only possible after the USA and the most important European tax havens were included into a co-operative scheme, and after the OECD initiative paved the way for worldwide co-operation in capital tax matters.

The introduction of the "political benefits from a sound and large financial market' as a second factor in the utility function of the governments reveals why the tax game has the structure of a dilemma rather than of a co-ordination game. Moreover, it shows that the heterogeneity of interests of EU member states is not only a consequence of asymmetry in size but also of different valuation of the two factors by governments. The two factors explain the actual policy preferences of the EU member state governments better than models that use only 'tax revenue' in the utility function.

These assumptions allowed the strategic constellation in the savings taxation case to be classified as an asymmetric dilemma, which combines a defection problem and a distributional problem. Thus, the problem is neither a simple defection game as implied in Genschel and Plümper (1997), nor a pure conflict game as in Dehejia and Genschel (1999). This model explains why it was so difficult to find an agreement at the EU level. Since the EU offers co-operative institutions, a symmetric dilemma should not have caused so many difficulties. The difficulties arose from the distributional problems.

What can we learn from this case in more general terms? Common good problems of the 'weakest-link' type are usually rather easy to solve. This is no longer the case, however, when the weakest-link character of the problem appears in combination with heterogeneous preferences of actors. The game becomes an asymmetric dilemma, a game that represents one of the most difficult cooperation problems to solve. It presupposes the presence of cooperative institutions in order to avoid defection after an agreement has been concluded. Moreover, the distributional problems involved make it difficult to find an agreement in the first place. Finally, heterogeneity of actors can have many different sources. In this 
case we found two types of preference heterogeneity, which together account for the extreme difficulties the EU had in finding a solution. More generally, identical game structures may have the same consequences, but they can result from many different factors. In order to identify the decisive factors in a single case, an approach combining empirical and theoretical work is necessary.

\section{Acknowledgements}

This paper was written as a contribution to the European Forum on 'Europe after Globalisation: Regulatory Co-operation and Regulatory Competition in an Integrating World Economy', while I was a Jean Monnet Fellow at the Robert Schumann Centre for Advanced Studies, European University Institute in Florence. I gratefully acknowledge the support of the Robert Schumann Centre. A number of colleagues provided valuable comments onearlier versions of this paper: three anonymous referees of Rationality and Society, Philipp Genschel, Thomas Plümper, Claudio Radaelli, Fritz W. Scharpf, and Hannes Winner.

\section{REFERENCES}

Bates, R.H., A. Greif, M. Levi, J.-L. Rosenthal and B. Weingast (eds). 1998. Analytical Narratives. Princeton, NJ: Princeton University Press.

Bernauer, T. 2000. Staaten im Weltmarkt. Zur Handlungsfähigkeit von Staaten trotz wirtschaftlicher Globalisierung. Opladen: Leske + Budrich.

Brennan, G. and J.M. Buchanan. 1980. The Power to Tax: Analytical Foundations for a Fiscal Constitution. Cambridge: Cambridge University Press.

Bucovetsky, S. and J.D. Wilson. 1991. 'Tax Competition with Two Tax Instruments.' Regional Science and Urban Economics 21: 333-50.

CEPS. 2001. EU Corporate Tax Reform. Report of a CEPS Working Party. Brussels: Centre for European Policy Studies.

Dehejia, V.H. and P. Genschel. 1999. 'Tax Competition in the European Union.' Politics \& Society 27: 403-30.

Devereux, M.P., R. Griffith and A. Klemm. 2002. 'Corporate Income Tax Reforms and International Tax Competition.' Economic Policy 35: 451-95.

Edwards, J. and M. Keen. 1996. 'Tax Competition and Leviathan.' European Economic Review 40: 113-34.

Eggert, W. 2000. Capital Tax Competition with Inefficient Government Spending. CoFE Discussion Paper No 99-15, Center of Finance and Econometrics, University of Constance, Germany. 
European Commission (EC). 1967. Program for the Harmonization of Direct Taxes. Communication by the Commission, Bulletin of the EC, Supplement 8 (1967): 6-22.

EC. 1988. Creation of an [sic] European Financial Area. Communication by the Commission, COM/87/550/final.

EC. 1989. Proposal for a Council Directive on a Common System of Withholding Tax on Interest Income, COM/89/69/final, OJ C 141, 07.06.89.

EC. 1996. Taxation in the European Union: Report on the Development of Tax Systems. COM/96/546/final, 22.10.96.

EC. 1998. Proposal for a Council Directive to Ensure a Minimum of Effective Taxation of Savings Income in the Form of Interest Payments within the Community. COM/98/ 0295/final - CNS 98/0193, OJ C 212, 08.07.98.

EC. 2001. Proposal for a Council Directive to Ensure a Minimum of Effective Taxation of Savings Income in the Form of Interest Payments within the Community. $\mathrm{COM} / 01 /$ 0400/final - CNS 01/0164, OJ C 270E, 25.09.01.

EC. 2002. Report on the Negotiations with Third Countries about the Taxation of Interests. Communication by the Commission to Council Ecofin, 03.12 .02 (internal document).

European Council/Ecofin 2000. Report on the Tax Package (Doc. 1355500 FISC 190). Santa Maria da Feira: European Council.

Eurostat 2001. Special Feature on Banking. Luxembourg: Office for Official Publications of the European Communities.

Frey, B.S. 1990. 'Intergovernmental tax competition,' in Charles McLure et al. (eds), Influence of Tax Differentials on International Competitiveness, pp. 89-114. Deventer: Kluwer Academic Publishers.

Frey, B.S. and R. Eichenberger. 1996. 'To Harmonize or Compete? That's Not the Question.' Journal of Public Economics 60: 335-49.

Fuest, C. 2000. 'The Political Economy of Tax Coordination as a Bargaining Game between Bureaucrats and Politicians.' Public Choice 103: 357-82.

Fuest, C. and B. Huber. 1999. 'Can Tax Coordination Work?' Finanzarchiv 56: $443-58$.

Genschel, P. 2002. Steuerharmonisierung und Steuerwettbewerb in der Europäischen Union. Frankfurt a.M.: Campus.

Genschel, P. and T. Plümper. 1997. 'Regulatory Competition and International Co-operation.' Journal of European Public Policy 4: 626-42.

Giovannini, Alberto and James R. Hines. 1991. 'Capital Flight and Tax Competition: Are There Viable Solutions to Both Problems?' in Alberto Giovannini and Colin Mayer (eds), European Financial Integration, pp. 172-220. Cambridge: Cambridge University Press.

Hahn, W. 1988. Steuerpolitische Willensbildungsprozesse in der Europäischen Gemeinschaft. Das Beispiel der Umsatzsteuerharmonisierung. Frankfurt a.M.: Peter Lang.

Hallerberg, M. 1996. 'Tax Competition in Wilhelmine Germany and its Implications for the European Union.' World Politics 48: 324-57.

Hirshleifer, J. 1983. 'From Weakest-link to Best-shot: The Voluntary Provision of Public Goods.' Public Choice 41: 371-86.

Holzinger, K. 2001. 'Aggregation Technology of Common Goods and its Strategic Consequences. Global Warming, Biodiversity, and Siting Conflicts.' European Journal of Political Research 40: 117-38. 
Kanbur, R. and M. Keen. 1993. 'Jeux sans frontières: Tax Competition and Tax Coordination When Countries Differ in Size.' Economic Review 29: 81-5.

Keen, M. 1993. 'The Welfare Economics of Tax Co-ordination in the European Community: A Survey.' Fiscal Studies 14: 15-36.

Koelliker, A. 2001. 'Bringing Together or Driving Apart the Union? Towards a Theory of Differentiated Integration.' West European Politics 24: 125-51.

Krause, H.-J. 2001. 'Harmonisierung der Zinsbesteuerung in Europa.' Die Bank 2001/ 3: 204-213.

Myles, G.D. 2000. 'Wasteful Government, Tax Evasion, and the Provision of Public Goods.' European Journal of Political Economy 16: 51-74.

OECD. 1998. Harmful Tax Competition. An Emerging Global Issue. Paris: OECD. OECD. 2000. Improving Access to Bank Information for Tax Purposes. Paris: OECD.

OECD. 2002. Agreement on Exchange of Information on Tax Matters. Paris: OECD: Available at: http://www.oecd.org/EN/document/0,,EN-document-22nodirectorate-no-12-2853-22,00 (accessed 16 February 2003).

Perman, R., Y. Ma and J. McGilvray. 1998. Natural Resources and Environmental Economics. London, New York: Longman.

Radaelli, C.M. 1998. 'Game Theory and Institutional Entrepreneurship: Transfer Pricing and the Search for Coordination in International Tax Policy.' Policy Studies Journal 26: 603-19.

Radaelli, C.M. 2003. 'The Code of Conduct against Harmful Tax Competition: Open Method of Coordination in Disguise?' Public Administration 81: 513-31.

Sandler, T. 1997. Global Challenges. An Approach to Environmental, Political, and Economic Problems. New York: Cambridge University Press.

Sinn, H.-W. 1990. 'Tax Harmonization and Tax Competition in Europe.' European Economic Review 34: 489-504.

Sinn, H.-W. 1997. 'The Selection Principle and Market Failure in Systems Competition.' Journal of Public Economics 66: 247-74.

Thomas, K.P. 2002. 'The Politics of an Emergent Global Regime for Controlling Tax Competition.' Policy Studies Journal 30: 270-84.

KATHARINA HOLZINGER is Professor of Political Science at Hamburg University. Research interests include rational choice, especially bargaining theory, the European Union, public goods, environmental policy, and financial markets. Recent publications: 'Bargaining by Arguing. An Empirical Analysis Based on Speech Act Theory', Political Communication 21 (2), 2004; 'Common Goods, Matrix Games, and Institutional Solutions', European Journal of International Relations 9 (2), 2003; 'Aggregation Technology of Common Goods and its Strategic Consequences. Global Warming, Biodiversity, and Siting Conflicts', European Journal of Political Research 40 (2), 2001.

ADDRESS: University of Hamburg, Institute of Political Science, Allende-Platz 1, D-20146 Hamburg, Germany [email: holzinger@sozialwiss.uni-hamburg.de]. 